\title{
PENGARUH PROGRAM KONSELING KOGNITIF SPIRITUAL TERHADAP KESALAHAN BERPIKIR KRIMINAL
}

\author{
Amalia Roza Brillianty \\ Universitas Negeri Padang \\ Sugiyanto \\ Universitas Gadjah Mada
}

\begin{abstract}
This study focuses on aggnitive aspect of criminal act. Intervention of the criminal thinking patterns merges the cognitive and spirituality princip/es. This Intervention called Cognitive Spirituel Counseling Program. The objective of this study $s$ to examine the influence of this program to the criminal thinking patterns on women prisoners.

The sample consisted of women prisoners who were incarcerated th a county jail h Padang as control group $(\mathrm{N}=10$ ) and Bukittinggl as experimental group $(\mathrm{N}=12)$. Level of the 10 criminal thinking patterns were assessed by 10 BKB Scale. 1

The result of ANOVA repeated measures showed that $F=6,414, p=0,020$. It means this program was effective to reduced the ten criminal thinking patterns. Three main pillar of this program decreased the level of thinking error were readiness and willingness of the subject, acceptance of the mentor and the material of the program. This program is unique considering it merges the cognitive and spirituality principles to reduced the criminal thinking patterns. This study also succesf ully revealed some factors that encouraged those criminal thinking paltems after the program. Those factors were included the perception of sentence, sociely's judgement, the environment they live in after the jeil and the fullilment of live necessitios. Capilalistic ivestyle also plays in maintaining criminal thinking pattems. We proposed this program would not successfully carried out without any other programs in prisons and should be done continously so that the number of prisoners would decrease.
\end{abstract}

Keywords: Criminal thinking pattems, Cognitive Spiritual Counseling Program, women prisoners

\section{Pengantar}

Peningkatan populasi penjara di Indonesia terutama wanita pada tahun 2001 terjadi hampir $100 \%$ sejak tahun 1994 (www.correct.go.id 2005). Biro Pusat Statistik (BPS, 1997) juga mencatat pada tahun 1997 terjadi peningkatan jumlah narapidana wanita sebesar $97,24 \%$ dari tahun 1991. Khusus untuk narapidana wanita kasus narkoba pada tahun 2001 adalah 164 orang (www.correct.go.ld 2005). Data ini menggambarkan betapa kriminalitas yang berakhir dengan pemenjaraan semakin bertambah. Tidak menutup kemungkinan ini pun berlaku bagi wanita, padahal tindakan penahanan mengandung dampak buruk tidak hanya bagi individu tetapi juga bagi negara (Barlow, 1984; Pomeroy, etal, 2000; Syirazi, 2004) 
Berbagai program dan kebijakan telah diterapkan untuk mengatasi semakin melonjaknya populasi penjara dan menanggulangi tingginya tingkat residivis. Program psikologi yang dinilai berhasil mengatasi masalah ini adalah programprogram yang menggunakan pendekatan kognitif (Baro, 1999; Pearson, ef al, 2002). Perspektif kognitif mengungkapkan balwa manusia memiliki potensi untuk menyerap pemikiran yang rasional dan irasional. Setiap individu mampu mengolah informasi sehingga dapat mengambil keputusan yang tepat, namun kebiasaan buruk pikiranlah yang menyebabkan kriminalitas. Pemikiran yang irasional dapat mendorong timbuinya gangguan emosi dan tingkah laku (Oemarjoedi, 2003).

Yochelson dan Samenow (Hall, 2003) mengidentifikasi 10 kesalahan berpikir para pelaku tindak kriminal. Kognisi atau pola pikir merupakan faktor yang mendorong kriminalitas ini dapat dimodifikasi karena berkaitan dengan karakteristik individual dalam menghadapi kehidupan yang diperoleh dari proses belajar. Oleh sebab itu, rekonstruksi kognitif perlu dilakukan untuk mengubah pikiran-pikiran kriminal tersebut (Baro, 1999).

Aspek spiritual penting bagi individu untuk mengatasi tekanan (Cole \& Pargament, 1999; Kaye \& Raghaavan, 2002; Pomeroy, et al, 2000). Masuk penjara merupakan sumber tekanan bagi individu (Pomeroy, et al, 2000). Spiritualitas membuat individu terus bertahan menghadapi tekanan kehidupan seperti berada di penjara, mendorong individu untuk terus berharap dan tidak mudah putus asa. Dengan demikian hidup akan dapat dijalani dengan lebih mudah. Para narapidana wanita juga mengakui bahwa mereka membutuhkan dukungan agama sebagai bekal dalam menjalani kehidupan setelah bebas dari penjara (Parson \& Warner-Robbins, 2002).

Pembinaan kerohanian memiliki peluang cukup besar dalam mengubah perilaku dan kebiasaan para narapidana. Hal (2003) mencoba menerapkan terapi kognitif dengan pendekatan agama untuk memperbaiki sepuluh bentuk kesalahan berpikir. Hasilnya bahwa perlakuan tersebut berpengaruh mengurangi tindakan pelanggaran dan meningkatkan kesempatan untuk dipindahkan ke blok khusus bagi narapidana yang berkelakuan baik.

Program Konseling Kognitif Spiritual (Program KKS) merupakan program pembinaan bagi warga binaan di lembaga pemasyarakatan dengan menggunakan prinsip-prinsip dasar pendekatan kognitif dan aspek spiritualitas untuk mengurangi kesalahan berpikir penyebab tindakan kriminal. Program KKS dirancang untuk memfasilitasi warga binaan wanita memperbaiki 10 kesalahan berpikir penyebab tindakan kriminal. Kemudahan program ini adalah seiring dengan pembinaan kerohanian di lembaga pemasyarakatan dan bisa dilakukan oleh pembina kerohanian. Pelaksanaan progran KKS dilakukan secara berkelompok sebanyak 7 kali pertemuan. Aspek spiritual yang digunakan dalam program KKS adalah islam. Islam memiliki pandangan yang sejalan dengan pendekatan kognitif yakni perilaku kriminal merupakan hasil dari proses berpikiryang keliru (An-Nabhani, 1953).

Keberadaan spiritualitas bisa tanpa agama namun pada umumnya agama merupakan jalan untuk mengembangkan spiritualitas yang lebih tinggi. Spiritualitas berhubungan erat dengan kekuatan yang lebih (maha) tinggi yaitu Tuhan (King, 1996). Spiritualitas bagi seorang yang beragama harus selalu dikaltkan dengan agama. Misalnya bagi seorang yang beragama Islam (muslim), makna hidup yang tidak didasari ajaran Islam akan sia-sia karena hanya bersifat keduniawian atau materi semata dan tidak akan mendatangkan kebahagiaan yang hakiki (An-Nabhani, 2001).

Dengan demikian salah satu upaya yang bisa dilakukan untuk mengatasi semakin melonjaknya kriminalitas yang berdampak pada peningkatan populasi penjara adalah melakukan perbaikan terhadap aspek kognitif penyebab kriminal. Diharapkan dengan menurunnya tingkat kesalahan berpikir penyebab kriminal dan terbentuknya pikiran baru maka setelah bebas dari lembaga pemasyarakatan para 
narapidana tidak akan kembali melakukan tindakan kriminal untuk memenuhi kebutuhan dan mencapal tujuannya.

\section{Tinjauan Pustaka}

Kesalahan Berpikir Penyebab Tindakan Kriminal

An-Nabhani (1953) menjelaskan bahwa perilaku seseorang tergantung bagaimana pandangan dan pemahamannya tentang kehidupan. Penyimpangan perilaku didasari oieh pemahaman yang keliru tentang cara memenuhi kebutuhan dasar dan nalurinya. Pemahaman yang keliru ini merupakan hasil proses berpikir berdasarkan informasi dari lingkungan yang tidak sesuai dengan Isiam. Perspektif kognitif juga mengungkapkan bahwa kriminailtas merupakan hasil darl kebiasaan buruk pikiran.

Yocheison dan Samenow (Blackburn, 1993) mengemukakan teori kepribadian kriminal yang didasari oleh pola pikir kriminal. Kesimpulan ini diperoleh berdasarkan penelitian terhadap 240 narapidana laki-laki di St. Elizabeth Hospital, Washington DC selama iebih dari satu dekade. Kriminalitas diartikan sebagai rangkaian panjang berupa kontinum yang luas dari proses berpikir. Sisi non kriminal terletak pada kutub yang diberi nama "pikiran dan tindakan yang bertanggung jawab", mencerminkan orang yang bermorai, memenuhi kewajiban dan mematuhi peraturan dan hukum. Kutub di seberangnya adalah kutub kriminal atau pikiran dan tindakan kriminal, menggambarkan seseorang dengan pola pikir keliru yang mendorongnya melakukan tindakan kriminal melaiui serangkalan pilihan. Yocheison dan Samenow (Hali, 2003) kemudian mengidentifikasi 10 kesaiahan berpikir para pelaku tindak kriminal yaitu berpikiran tertutup, diri baik, diri adalah korban, menyerah saja, pamrih, tidak berpikir panjang, ketakutan pada diri sendiri, percaya hukum rimba, diri istimewa dan kepemilikan.

\section{Program Konsellng Kognitif Spiritual (Program KKS)}

Saiah satu jenis program pembinaan d penjara yang paling banyakdigunakan dan berhasil adaiah pendekatan kognitif keperilakuan (Waiters, 1999; Baro,1999; Amstrong, 2003). Pendekatan kognitif efektif untuk mengembangkan perilaku positif dan mengurangl pemikiran irasionai yang menimbulkan perilaku krimina! (Pearson, et al, 2002). Michigan Reformatory di lona teiah mulai mengembangkan Program Restrukturisasi Kognitif terhadap para narapidana. Program disebut Strategies Thinking Productively (STP) yang terdirt dari dua tahap yaitu STP tahap 1 dan tahap 2 . Narapidana yang menglkuti STP tahap 1 menunjukkan penurunan dalam hai perilaku menolak perintah langsung sedangkan partisipasi pada STP tahap 2 menunjukkan penurunan perilaku penyerangan (Baro, 1999).

Program KKS menggabungkan antara prinsip kognitif dan aspek spiritualitas untuk memperbalki sepuluh kesalahan berplkir kriminal. Prinsip-prinsip pendekatan kognilif yang digunakan untuk memperbaiki kesalahan berplkir adalah konfrontasi, penggunaan humor, memperkokoh kemauan, memantapkan keteguhan hati, memfasiitasi asertifitas, meneguhkan konsistensi, memupuk minat sosial, bermain peran, membayangkan, membuka poia pikir, dan tugas rumah (Werner, 1982). Pendekatan spiritualitas yang dipakal dalam program KKS adaiah menurut ajaran Islam. Konsep Islam yang digunakan untuk memperbaki sepuluh kesalahan berpikir adalah cerita-cerita hikmah, materi keislaman seperti potensi manusia, fungsi akai, wilayah-wilayah kehidupan manusia serta pembiasaan dalam berdoa. Doa merupakan bentuk spirituailtas yang banyak digunakan dalam terapi karena dengan berdoa maka individu akan memiliki harapan (Kaye \& Raghaavan, 2002).

Para peserta program KKS diminta untuk mengidentifikasi 10 kesalahan berpikir kriminal yang ada pada diri mereka. Kemudian peserta mendiskusikan bagaimana kesalahan berpikir tersebut bisa 
mendorong munculnya tindakan kriminal. Pemandu menjelaskan bagaimana ajaran Islam memandang kesalahan berpikir tersebut. Terakhir, masing-masing peserta diminta untuk mencari altematif pikiran baru.

Pertemuan awal program KKS akan menjelaskan tentang potensi manusia dan fungsi akal. Peserta diajak untuk memikirkan, "Slapa saya ? Darimana saya berasal ? Untuk apa saya hidup ? Akan kemana saya setelah kehidupan ini ? peserta terlebih dahulu harus memahami arti keberadaan dirinya. Kemudian akan dijelaskan tentang proses terjadinya perilaku dari sudut pandang kognitif yaitu bahwa perilaku seseorang dipengaruhi oleh pandangan dan pemahamannya tentang kehidupan dan perilaku kriminal didasari oleh pola pikir yang salah tentang bagaimana Indivldu memenuhi kebutuhan dasardan naluri tersebut.

\section{Hipotesis}

Ada perbedaan tingkat kesadaran berplkir antara sebelum dengan sesudah mengikuti program konseling kognitif. Program Konseling Kognitif Spirituai dapat menurunkan tingkat kesalahan berpikir penyebab kriminal.

\section{Metode Penelitian}

\section{Identifkasl Variabel Penelitian}

Variabel bebas dalam penelitian ini adalah Program KKS. Variabel tergantung adalah kesalahan berpikir penyebab krimlnal.

\section{Definisi Operasional Variabel Penelitian}

Program Konseling Kognitif Spiritual (Program KKS) adalah suatu program yang dirancang untuk memperbaiki 10 kesalahan berpiklr penyebab kriminal dengan menggabungkan dua pendekatan yaitu kognitifdan spiritual.

Kesalahan berpiklr penyebab kriminal adalah pikiran yang mendorong seseorang untuk melakukan tindakan kriminal. Kesalahan berpikir tersebut meliputi berp|kiran tertutup, menganggap diri baik, menganggap diri adalah korban, menyerah saja, harus ada pamrih, tidak berpikir panjang, ketakutan pada diri sendiri, percaya hukum rimba, merasa diri istimewa dan kepemilikan.

\section{Rancangan Penelitian}

Penelitian menggunakan rancangan dua kelompok pretes dan postes. Kelompok eksperimen dpberikan perlakuan yaitu program KKS sedangkan kelompok kontrol dijadikan sebagai pembanding yang tidak mendapatkan program KKS. Penilaian kesalahan berpikir kedua kelompok dilakukan sebelum dan setelah program untuk mengetahui pengaruh program.

\section{Manipulasi Variabel independen}

Jumlah pertemuan Program KKS adalah 2 kali pertemuan per minggu total 7 kali pertemuan, selama 120 menit. Setiap pertemuan akan membahas dua bentuk kesalahan berpiklr. Peserta secara bergantian mengungkapkan pikirannya sesual dengan bentuk kesalahan berpikir yang dlbahas saat itu. Peserta lain menanggapl kesesuaian cerita dengan bentuk kesalahan berpikir dan menjelaskan bagaimana tindakan kriminal muncul. Terakhir pemandu meminta peserta untuk merangkum pernyataan yang mencerminkan kesalahan berpikir dan mendorong peserta untuk mencari alternatif pikiran baru. Pemandu kemudian menyampaikan materi keislaman yang berkaitan dengan bentuk kesalahan berpikir. Setiap pertemuan peserta diminta membuat catatan harian yang menceritakan riwayat hidupnya, kronologis kasus, bentuk kesalahan berpikir yang mendorong la melakukan tindakan kriminal dan pengalaman selama berada of lembaga pemasyarakatan.

\section{Kriteria Pemandu Program}

Kriteria pemandu program KKS adalah wanita, memiliki pemahaman mengenai Islam, berpengalaman melakukan pembinaan terhadap masyarakat seperti membina kelompok pengajian, mengetahui prinsip dasar psikologi dan pendekatan kognitif, empati, dan mampu membina hubungan interpersonal dengan orang lain.

\section{Subjek}


Penelitian melibatkan 22 warga binaan Wanita, 12 warga binaan wanita di Lembaga Pemasyarakatan Bukittinggi sebagai kelompok eksperimen dan 10 warga binaan wanita di Lembaga Pemasyarakatan Padang sebagai kelompok kontrol. Pemilihan subjek kelompok eksperimen melibatkan semua warga binaan wanita yang jumlahnya terbatas, sedang subjek kelompok kontrol dipilih secara acak ofeh petugas lembaga pemas yarakatan.

Kejahatan yang paling banyak dilakukan oleh warga binaan wanita adalah berkaitan dengan kasus narkoba dan kejahatan lain yang berhubungan dengan uang untuk pemenuhan kebutuhan hidup seperti pencurian, penipuan dan penggelapan.

\section{Skala 70BKB}

Skala 10 BKB digunakan untuk menilal tingkat kesalahan berpikir kriminal. Skala terdiri dari 10 bentuk kesalahan berpikir kriminal yang diturunkan menjadi 10 aitem. Pilihan jawaban bersifat kontinum yang terdiri dari 4 pllihan, yaitu Sering, Kadangkadang, Jarang Sekali, Tidak Pernah. Skor berkisar antara 0-3. Skor 0 untuk pilihan jawaban Tidak Pernah, dan 3 untuk pilihan Sering. Total Skor adalah 30 . Semakin tinggi skor menunjukkan semakin tinggi tingkat kesalahan berpikirsubjek.

\section{Prosedur Penelitian}

Kedua kelompok penelitian berada di dua lembaga pemasyarakatan yang terpisah. Sebelum program dimulai, dilakukan penilaian tingkat kesalahan berpikir penyebab kriminal pada semua subjek. Program untuk kelompok eksperimen dimulai satu minggu setelah pretes. Peserta di kelompok eksperimen diberikan penjelaskan tentang program, perkenalan antara peneliti dan peserta secara keseluruhan. Selanjutnya diłaksanakan pertemuan untuk membahas masing-masing dua bentuk kesalahan berpikir dalam satu pertemuan. Pengukuran 10 kesalahan berpikir, kembali dilakukan satu minggu setelah program KKS berakhir untuk kelompok eksperimen. Setelah semua data terkumpul dilakukan pengolahan dan analisis data.

\section{Analisis Data}

Untuk mengetahui pengaruh program Konseling Kognitif Spiritual terhadap kesalahan berpikir penyebab kriminal dilakukan analisis varian campuran terhadap hasil pretes dan postes kedua kelompok.

\section{Hasil Penelitlan}

Tabel.t

Hasil Uji Hipoteses

\begin{tabular}{|l|r|r|r|r|r|r|}
\hline \multicolumn{1}{|c|}{ Sumber } & JK & db & MK & F & P & $\begin{array}{c}\text { Eta } \\
\text { Kuadrat }\end{array}$ \\
\hline Bentuk Kesalahan Berpikir & & & & & & \\
Bentuk Kesalahan Berpikir * & 12,027 & 1 & 12,027 & 0,76 & & \\
Kelompok & 101,482 & 1 & 101,48 & 6,41 & 0,394 & 0,037 \\
Kelompok & 68,182 & 1 & 2 & 4 & 0,020 & 0,243 \\
& & & 68,182 & 3,70 & 0,068 & 0,156 \\
& & & 8 & & \\
\hline
\end{tabular}


Pada Tabel 1, nilai F sebesar $6,414(p=0,020)$ membuktikan bahwa hipotesis penelitian yaiku Program KKS dapat menurunkan tingkat kesalahan berpikir penyebab kriminal diterima atau terbukti. Nilai eta kuadrat sebesar 0,243 berarti bahwa Program KKS memberikan sumbangar sebesar $24.3 \%$ terhadap penurunan tingkat kesalahan berpikir.

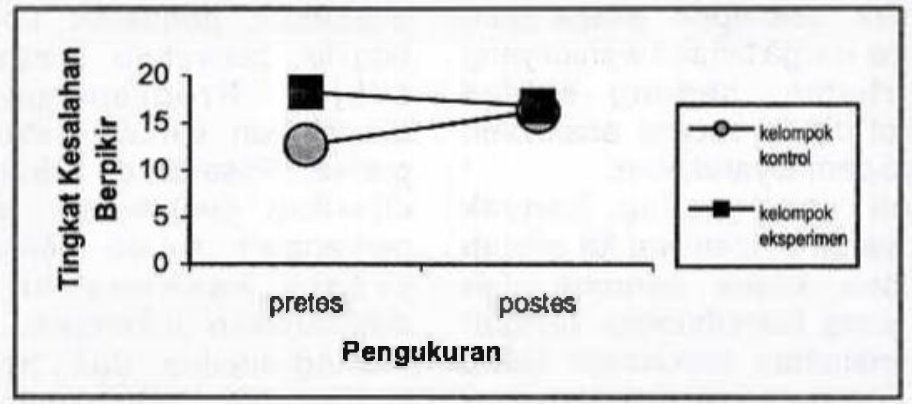

Gambar 1 Profil Tingkat Kesaiahan Berpikir

Gambar 1 menunjukkan tingkat kesalahan berpikir pada kelompok kortirol mengalami peningkatan. Diduga hal ini terjadi karena adanya interaksi antar warga binaan warita di dalam LP. Pada umumnya subjek di kelompok kontrol masuk penjara bersama dengan teman-teman pesta narkobanya sehingga dimungkinkan tejadi pertukaran informasi negatif yang semakin memperkuat tingkat kesalahar berpikir subjek. Hai ini sesuai dengan uraian Blackburn (1994) bahwa tindakan kriminal dipelajari melalui interaksi sosial secara intensif dalam kelompok baik teknik ataupun motif, dorongan dan alasan kejahatan.

\section{Pembahasan}

Hasil analisis menunjukkan bahwa program KKS memberikan pengaruh yang signifikan terhadap penururian tingkat kesalahan berpikir kriminal para warga binaan wanita di lembaga pemasyarakatan. Thga pllar program KKS yang dianggap mampu memberikan kontribusi terhadap keberhaslian dalam menurunkan tlngkat kesaiahan berpikir warga binaan wanita adalah kesungguhan peserta, penerimaan dan kehangatan pemandu, materi program.

Peserta terlihat antusias dan aktif mengikuti pertemuan. Sebagian besar subjek, baik secara lisan ataupun melalui lembar Harapan dan Kekhawatiran yang ditulis pada awal sesi, menyatakan bahwa mereka mau berubah dan sangat bersyukur ketika ada yang membimbing. Peserta mengharapkan agar program dilaksanakan kembali dengan durasi waktu yang lebih lama, frekuensi kedatangan yang lebih sering disertai sesi konseling individual.

Pemandu mampu menunjukkan kehangatan terhadap peserta misalnya dengan memberikan pemyalaan-pemyataan yang spontan dan tulus terhadap permasalahan peserta. Pemandu tidak meiakukan konfrontasl secara langsung namun melalui perumpamaan dan berusaha mengaitkan pertanyaan dengan materi sebelumnya. Hubungan yang terbina antara pemandu dan peserta dalam program KKS adalah hubungan yang saling percaya, penuh penerimaan, sehlngga memungkinkan klien untuk belajar menghadapi, mengekspreslkan dan mengatasi perasaan atau pikiran yang mengariggu (Ohisen, 1970). Konseling kelompok seperti ini akan membuat peserta merasa nyaman dan antusias untuk menerapkan apa yang teiah mereka pelajari, Pemandu juga mengakul bahwa la merasa 
nyaman menjalankan tugasnya karena penerimaan yang baik dari petugas dan kesediaan peserta mengikuti program sehingga pemandu merasa apa yang dilakukannya memang memberi kontribusi terhadap pembinaan di lembaga pemasyarakatan.

Materi Program KKS yang unik yaitu dengan menggabungkan prinsip-prinsip kognitif dan aspek spiritual yang secara bertahap menggunakan prinsip sebab akibat sehlngga dapat mengaktifkan proses berplkir subjek. Peserta difasilitasi untuk menggali kesalahan berpikimya dan menyadari bahwa ada akibat tertentu dari kesalahan berpikir tersebut. Penanaman informasi juga diberikan melalul umpan balik permainan atau menganalisa suatu perumpamaan. Pemlkiran Iraslonal dibongkar dengan menggunakan prinsip-prinsip kognitif seperti bermain peran, konfrontasi, dan membayangkan. Aspek spirltualitas digunakan sebagai pemelihara setelah peserta menyadari kesalahan berpikir mereka dengan membangkitkan kesadaran akan hubungan dengan pencipta yakni menjalani hidup sesuai dengan aturan penclpta dan setiap perbuatan akan dipertanggungjawabkan. Materi-materi seperti simpul kehidupan, lingkar wilayah dan demi masa (taubat) berperan dalam penjagaan harapan. Pada umumnya peserta meyakini bahwa la masih punya kesempatan untuk menjadi lebih baik, menjadi lebih terbuka terhadap perubahan dan tidak lagi memandang masa depan mereka penuh dengan kesuraman.

Kesalahan berpikir yang dominan pada subjek adalah menganggap bahwa diri adalah korban dan segala sesuatu baik orang ataupun benda adalah untuk dimiliki. Para peserta meyakinl bahwa mereka adalah korban terutama dari kondls| ekonomi yang serba sulit. $\mathrm{Hal}$ inilah yang kemudian memaksa mereka untuk melakukan perbuatan kriminal. Menurut mereka, materi atau uang adalah jaminan untuk dapat hidup layak sehingga apapun akan mereka lakukan untuk mendapatkan jaminan tersebut walaupun harus dengan melakukan perbuatan kriminal. Kesalahan berpikiryang paiing berhasil diperbaiki dalam program ini adalah kesalahan berpikiran tertutup, tidak pikir panjang dan merasa diri istimewa .

Beberapa keterbatasan dalam pelaksanaan program ini, di antaranya pemandu masih kurang berpengalaman menggunakan pendekatan kognitif seperti kekurangpekaan pemandu untuk menangkap pemyataan-pemyataan spontan yang mencerminkan kesaiahan berpikir seperti penggunaan kata "selalu", "saya pasti akan", "tidak seorang pun". Peserta kurang disiplin dalam menyelesalkan tugas rumah padahal salah satu kekuatan terapi / konseling dengan menggunakan pendekatan kognitif adalah pemberian tugas rumah (Werner, 1982). Jumlah anggota kelompok yang melebihl kapasitas. Permintaan dari pihak lembaga pemasyarakatan untuk mengikutsertakan semua warga binaan dalam kelompok eksperimen, membuat jumlah keiompok menjadi 12 orang. Yalom (1975) mengungkapkan bahwa jumlah yang efektif dalam melaksanakan terapi kelompok adalah 7 orang atau maksimal 10 orang. Jumlah peserta yang melebihi kapasitas cukup mempengaruhi jalannya program seperti tidak semua peserta mendapat perhatian dan kesempatan yang sama untuk mengungkapkan masaiahnya, pemandu lebih hafal pada peserta yang aktif, peserta membentuk forum sendiri dengan berbicara dengan teman sebelahnya karena pemandu berbicara dengan peserta lain tanpa melibatkan kelompok.

Penelitian ini juga mengungkap bahwa ada beberapa faktor yang menyebabkan tingkat kesalahan berplkir warga binaan tetap tinggi sehingga menghambat keberhasllan program KKS dalam menurunkan kesalahan berpikir. Faktor penghambat tersebut meliputi persepsi terhadap hukuman. penerimaan masyarakat, lingkungan tempat kembali dan kecukupan kebutuhan hid up.

\section{Penutup}

Program Konseling Kognitif Spiritual berhasil menurunkan tingkat kesalahan 
berpikir warga binaan wanita di lembaga pemasyarakatan. Keberhasilan program KKS ditentukan oleh tiga pilarutama program yaitu pemandu, peserta dan materi yang merupakan gabungan prinsip kognitif dan aspek spiritual. Dua kesalahan berpikir yang dominan adalah Aku adalah Korban dan Kepemilikan. Kesalahan berpikir yang paling berhasil diperbaiki melalui program KKS adalah Berpikiran Tertutup, Tidak Pikir Panjang dan Diri Istimewa. Empat faktor yang menghambat keberhasilan program KKS dalam menurunkan kesalahan berpikir yaitu persepsi terhadap hukuman, penerimaan masyarakat, lingkungan tempat kembali dan kecukupan kebutuhan hidup.

Beberapa saran yang dapat disampaikan untuk penelitian lanjutan adalah melakukan studi pendahuluan yang lebih mendalam mengenai kesalahan berpikir penyebab perilaku kriminal sehingga to kesalahan berpikir para pelaku kriminal dapat didentifikasi dengan tepat. Program Konseling Kognitif Spiritual tidak berdiri sendiri tapi merupakan bagian pembinaan d lembaga pemasyarakatan dan dilakukan secara berkesinambungan.

\section{Daftar Pustaka}

Amstrong, T. A. 2003. Effect of Moral Reconation Therapy on the recidivism of youthful offenders. Criminal Justice and Behavior, 30 , 668-687.

An-Nabhani, T. 1953. Nizham AIs/slam. Beirut: HizbutTahrir.

An-Nabhani, T. 2001. Peraturan Hidup dalam Islam. Bogor: Pustaka Thariquil Izzah.

Barlow, H.D. 1984. Introduction to Criminology. Toronto: Little, Brown \&Company.

Baro, A 1999. Cognitive Restructuring Program on Immates. Criminal
Justice and Behavior, 26, 466-484.

Biro Pusat Statistik. 1997. Data Tindak Kriminal di Indonesia. Diakses tanggal 22 Oktober 2004, dari http//www.bps.go.id

Blackburn, R 1994. The psychology of criminal conduct; Theory, research and practice. Chichester : John Wiley \& Sons Inc.

Cole, B \& Pargament, K 1999. Re-Creating Your Life:A spiritual / psychotherapeutic intervention for people diagnosed with cancer. Psychomoncology, 8, 395407.

Hall, S. T. 2003. Faith-based cognitive programs in corrections. CorrectionsToday,65, 10-116.

Kaye, J., \& Raghavan, S. K. 2002. Spirituality in disability and illness. Journal of Religion and Health, 41, 231-242.

King.A. S. 1996. Spirituality: Transformation and Metamorphosis. Religion, 26, 343351.

Oemarjoedi, A K 2002. Pendekatan Cognitive Behavior daram Psikoterapi. Jakarta: Penerbit KreatifMedia.

Ohisen, M. M .1970. Group Counseling. New York: Holt, Rinehard and Winston, Inc.

Parson, M. L., \& Warner-Robbins, Carmen. 2002. Factors that support women's sucessful transition to the community following jail / prison. Health Care for Women international, 23, 6-18.

Pearson, F. S., Lipton, D.S., Cleland, C. M., \& Yee, D. S. 2002. The effect of behavioral / cognitif-behavioral programs on recidivism. Crime \& Delinquency, 48, 476-496. 
Pomeroy, E C., Kiam, R., \& Green D. L. 2000. Reducing depression, anxiety and trauma of male inmates: An HIV/AIDS psychoeducational group intervention. Social Work Research,24(3), 156166.

Prosentase rata-rata pertahun jumlah penghuni (tahanan, narapidana dan anak didik) diukur dengan kapasitas Lapas / Rutan. Diakses pada 23 Januari 2005, dari http://www.correct go.id/ind/stsubs .htm.

Rata-rata pertahun jumlah narapidana (dewasa dan pemuda) pada Lapas /Rutan seluruh Indonesia. Diakses pada 23 Januari 2005, dari http://www.correct.go,id/ind/stsubs .htm.
Rata-rata tahanan/narapidana kasus narkoba pada tahun 2001 di seluruh Indonesia. Diakses pada 23 Januari 2005 , dari http://www.correct.go.d//ind/stsubs .htm.

Syirazi, I. M., 2004. Islam Melindungi HakHak Tahanan. Jakarta: Pustaka Zahra.

Walters, G.D. 1999. Short-Term Outcome of inmates participating in the Lifestyle Change Program. Criminal Justice and Behavior, 26(3), 322-337.

Wemer, H D. 1982. Cognitive Therapy:A Humanistic Approach. New York The Free Press.

Yalom, I. D .1975. The Theory and Practice of Group Psychotherapy. Second Edition. New York: Basic Book, Inc. 